\title{
KEMANFAATAN RUANG UTAMA \\ PADA MASJID AGUNG ISLAMIC CENTER KOTA LHOKSEUMAWE
}

\author{
Bambang Karsono1, Julaihi Wahid ${ }^{2}$, Irma Yunita Sari ${ }^{3}$ \\ ${ }^{1,3}$ Program Studi Arsitektur, Fakultas Teknik, Universitas Malikussaleh, Indonesia \\ ${ }^{2}$ Fakulti Kejuruteraan, Universiti Malaysia Sarawak, Malaysia \\ Jl. Cot Teungku Nie, Reuleut Tim., Muara Batu, Kabupaten Aceh Utara, Aceh

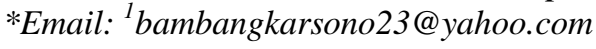

\begin{abstract}
ABSTRAK
Banyak perancangan ruang pada masjid dihasilkan dari sebuah duplikasi dan peniruan terhadap tipologi ruang dari bangunan masjid lain yang dianggap baik sebagai produk masyarakat muslim. Pendekatan ini terbatasi dengan pengunaan ruang utama berupa ruang di tengah yang paling besar yang dipergunakan untuk sholat dan seringkali mengabaikan nilai dan prinsip dasar Islam yang bersumber dari Al-Qur'an dan Sunnah. Artikel ini berusaha mengungkap kemanfaatan ruang utama pada Masjid Agung Islamic Center (MAIC) di Kota Lhokseumawe dikaitkan dengan 'menghindari berlebih-lebihan' yang merupakan salah satu nilai dan prinsip dasar Islam. Pengamatan dilakukan selama 30 hari, paralel dengan eksplorasi nilai dan prinsip Arsitektur Islami yang bersumber dari Al-Qur'an dan Sunnah. Temuan penelitian menunjukkan bahwa kemanfaatan ruang utama pada MAIC rata-rata hanya 3,24\% menurut hari dan 3,26\% menurut waktu sholat hal ini menunjukkan indikasi kemubaziran. Kajian ini diharapkan dapat menjadi diskusi bagi pengembangan ranah perancangan dan pemikiran Arsitektur Islami yang lebih bernilai khususnya di Aceh.
\end{abstract}

Kata Kunci: Masjid, Ruang Utama, Berlebih-Lebihan, Kemubaziran.

\section{PENDAHULUAN}

Masjid Agung Islamic Centre (MAIC) Kota Lhokseumawe terletak di pusat Kota Lhokseumawe pada areal seluas 33,748,47 $\mathrm{m}^{2}$. Pada lahan tersebut saat ini telah ada bangunan Masjid seluas $16.475,80 \mathrm{~m}^{2}$. Di dalam masjid ini terdapat ruang utama dengan luas $3.558,33 \mathrm{~m}^{2}$ yang dipergunakan untuk sholat, serta ruang lainnya seperti: sekretariat, ruangan imam, kamar imam, ruangan cleaning service, kamar imam, aula, tempat wudhuk pria dan wanita serta fasilitas perkantoran dan unit-unit lain. Secara administratif, MAIC berada pada Kecamatan Banda Sakti Kota Lhokseumawe. Kecamatan ini memiliki luas wilayah 112,40 hektar dengan jumlah penduduk 80.769 jiwa yang tersebar pada 18 gampong (desa) dengan rasio setiap 100 perempuan berbanding 99,66 laki laki. Selain MAIC ada 13 mesjid lain yang tersebar pada gampong di Kecamatan Banda Sakti. Jika diambil pendekatan luas ruang 0,72 $\mathrm{m} 2(0,6 \mathrm{~m} \times 1,2 \mathrm{~m})$ per-orang untuk melakukan sholat, maka ruang utama MAIC seluas $3.558,33 \mathrm{~m} 2$ dapat menampung jemaah sebanyak 4.942 orang (Gambar 1).

Al-Hadits banyak menjelaskan berbagai referensi mengenai penggunaan dan fungsi masjid semasa hidup Rasulullah SAW, khususnya pada Masjidil Haram di Mekah dan Masjid Nabawi di Madinah. Dan selayaknya umat Islam meneladani sikap dan perilaku Rasullulah SAW dalam mendesain dan memanfaatkan ruang masjid. Kisah tentang kehidupan sosial di sekitar Ka'bah menceritakan bahwa masjid digunakan sebagai tempat berkumpul bagi semua masyarakat dan bangsawan Arab. Kegiatan politik dan urusan diplomatik dilakukan berdekatan dengan Ka'bah. Rasulullah banyak melakukan diskusi dan dakwah/ceramah di Masjidil Haram.

Hal ini menggambarkan bahwa pemahaman tentang tempat 'sanctity' (kesucian) bukanlah 
tempat yang hanya digunakan untuk kegiatan ibadah rutin saja. Masjid Nabawi di Madinah juga digunakan dengan cara yang sama sebagai pusat kegiatan sosial, politik dan ibadah. Beberapa hadits menjelaskan fungsi sebagai shelter, institusi pendidikan, fasilitas kesehatan, perayaan dan kegiatan rekreasi juga dilakukan di dekat Masjid Nabawi.

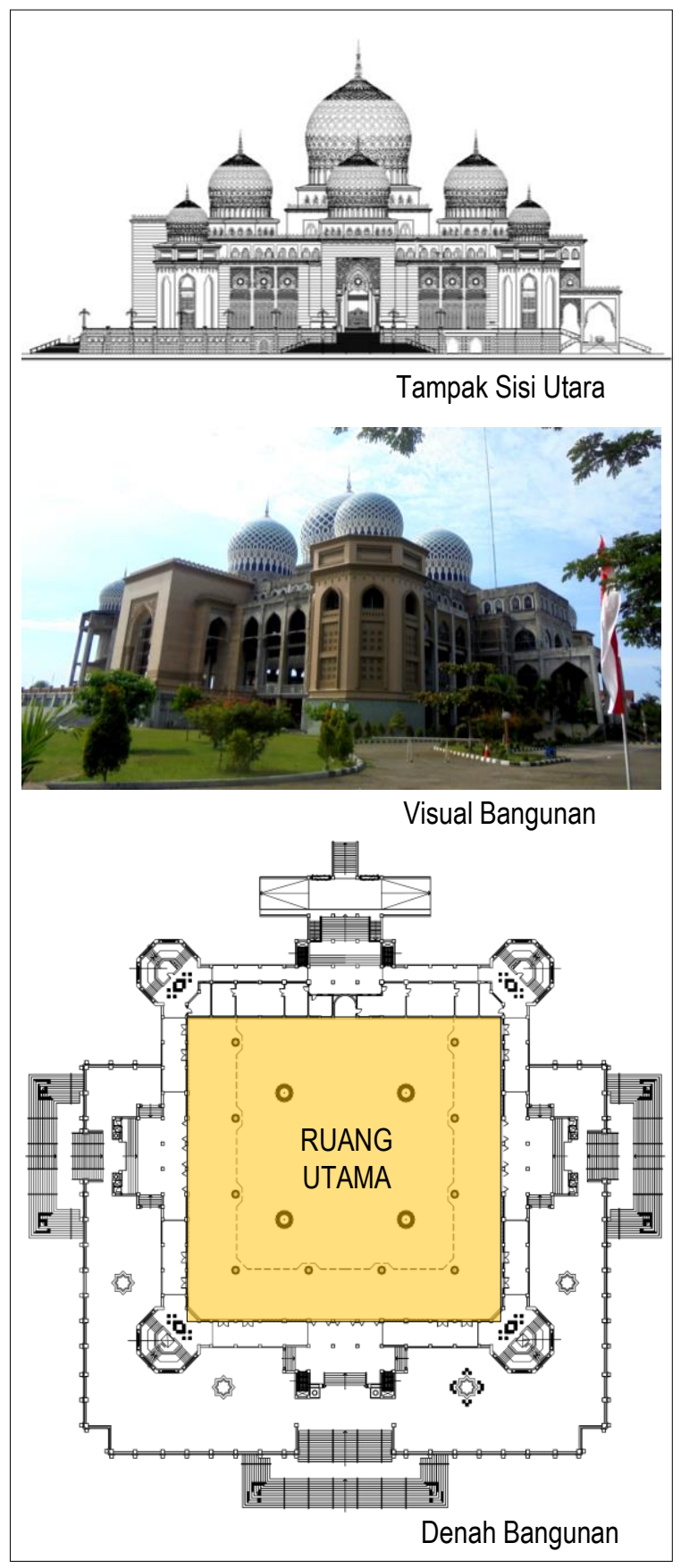

Gambar 1. MAIC Kota Lhokseumawe

Secara arsitektural, ruang-ruang yang ada di Masjid Nabawi pada Rasulullah SAW merupakan ruang-ruang yang sangat fleksibel dan multifungsi. Ruang-ruang ini memiliki kemanfaatan yang sangat besar dan tidak tersiasiakan begitu saja. Halaman luas yang dikelilingi oleh tembok membuat area tersebut cukup aman dan nyaman untuk kegiatan shalat berjamaah, berlatih fisik, berolahraga, berkumpul dan bermusyawarah, serta belajar. Ruang-ruang yang beratap juga dapat dimanfaatkan untuk berbagai aktivitas secara fleksibel, di antaranya sholat berjamaah, menuntut ilmu dan bermusyawarah. Tentu saja keberadaan halaman yang luas sebagai tempat sholat berjamaah ini dimungkinkan sesuai dengan konteks wilayah dan iklim di Madinah dan Jazirah Arab yang kering dan jarang hujan.

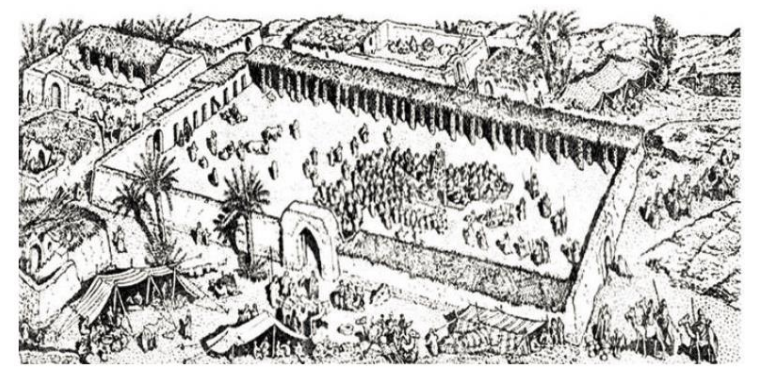

Gambar 2. Ilustrasi Masjid Nabawi pada jaman Rasullulah SAW, dengan berbagai aktifitas dan semangat ke-Islamannya

Rasulullah SAW mengingatkan umat muslim untuk tidak berlebih-lebihan dalam membangun masjid seperti pada hadith berikut:
Ibnu 'Abbas r.a. berkata, bersabda
Rasulullah s.a.w.:
"Aku tidak diperintah mendirikan mesjid tinggi-tinggi” (H.R. Abu Dawud)

Anas ibn Malik r.a. menerangkan,
bahwasanya Nabi s.a.w. telah bersabda:
"Tiadalah terjadi kiamat, sehingga manusia
bermegah-megahan dan berlebih-lebihan
dalam urusan-urusan pembinaan mesjid"
(H.R. Ahmad, Abu Daud, An-Nasa'I dan
Ibnu Majah)

'Masjid tinggi' dalam hadits tersebut tidak dapat dipahami hanya secara literal namun juga berkonotasi sebagai berlebih-lebihan dalam hal ruang dan konstruksi. Sehingga pemahaman tentang masjid bukanlah suatu bangunan monumental yang difungsikan hanya untuk 
ritual ibadah saja. Masjid seharusnya suatu tempat bagi umat muslim berkumpul untuk berinteraksi dan melakukan berbagai tanggung jawab sehingga bermanfaat bagi Islam. Menurut Islam, masjid sebagai rumah untuk ibadah memiliki pemahaman dan konotasi yang berbeda dibandingkan dengan agama lain.

Rasulullah melarang umatnya untuk berlebih-lebihan dalam segala hal termasuk di dalamnya bagaimana mendirikan bangunan dan memilih bahan untuk bangunan. Islam berbicara tentang bahasa arsitektural yang sederhana, rendah hati dan fungsional sebagaimana terlihat pada riwayat hadith berikut ini :

"Annas bin Malik berkata: Rasulullah SAW suatu hari melihat sebuah bangunan besar dengan kubah diatasnya kemudian berkata: Apakah itu ? Para sahabat menjawab: Itu merupakan bangunan milik fulan..., salah seorang dari kaum Anshor. Rasulullah tidak mengucapkan sepatah kata pun sehingga menimbulkan tanda tanya besar. Ketika pemiliknya memberikan salam kepadanya Rasulullah memalingkan wajahnya dan melangkah pergi. Si pemilik ini mengulanginya berulangkali dan reaksi Rasulullah tetap sama, sehingga orang tersebut menyadari bahwa kemarahan Rasulullah karena ia. Sehingga akhirnya ia menanyakan hal tersebut kepada sahabat yang lain dengan berkata: Saya bersumpah demi Allah bahwa saya tidak memahami sikap Rasulullah SAW. Para sahabat menjawab ia bertindak seperti itu setelah melihat bangunan besar dengan kubah milikmu. Sang sahabat itu kemudian pulang ke rumahnya dan menghancurkannya sehingga rata dengan tanah. Suatu hari Rasulullah melihat ke arah yang sama dan tidak melihat bangunan kubah itu lagi. Ia bertanya: Apa yang telah terjadi pada bangunan berkubah tersebut? Mereka (para sahabat) menjawab: "pemiliknya mengeluh bahwa kau (Rasulullah SAW) memalingkan wajahmu ketika berjumpa dengannya dan ketika kami memberitahukan sebabnya dia pun menghancurkannya. Rasulullah berkata: "Setiap bangunan adalah fitnah bagi pemiliknya kecuali yang tanpanya manusia tidak dapat hidup". (Sunnah Abu Dawud, Vol. III, hal 14441445)

Kemanfaatan ruang merupakan nilai yang sangat mendasar dalam berarsitektur. Ketiadaan manfaat dapat menyebabkan kemubaziran dan timbulnya mudharat pada suatu hal, apalagi jika hal tersebut dilakukan berulang-ulang dan berlebih-lebihan. Pengetahuan dan pemahaman akan kaidah-kaidah kemanfaatan dan penghindaran kemudharatan di dalam Islam sangat bermanfaat sebagai jalan untuk memperoleh maslahat dan menolak mafsadat dalam berarsitektur. Dari uraian hadits diatas memberi gambaran tentang semangat kesederhanaan dan keindahan sebenarnya yang terdapat dalam Islam.

\section{METODE PENELITIAN}

Metode yang digunakan dalam penelitian ini adalah studi kasus normatif (normative case study) yang bertujuan untuk mengembangkan pengetahuan secara intensif tentang satu objek (Zeisel,1980). Kajian dilakukan dengan mengumpulkan beberapa hadits-hadits yang kemudian diuraikan dan dijadikan kerangka rujukan untuk menelaah kemanfaatan ruang utama masjid.

Pengumpulan data diperoleh melalui pemetaan dimensi ruang utama masjid, mengamati dan mengukur pemanfaatan ruang pada setiap 5 waktu sholat wajib berjamaah dan sholat fardhu Jum'at. Pengamatan dan pengukuran dilakukan selama 30 hari. Data pengamatan yang diperoleh dicatat dan dikompilasi dalam tabel menurut kronologi kegiatan. Data pengukuran berupa luas ruang yang termanfaatkan pada setiap waktu sholat berjamaah termasuk Sholat Fardhu Jum'at. Data ini dikompilasi menggunakan program microsoft excel dalam bentuk tabel dan diagram. Analisis dan diskusi dilakukan dengan melakukan telaah terhadap fenomena pemanfaatan ruang utama yang terjadi terkait dengan pengetahuan dan pemahaman akan kaidah-kaidah kemanfaatan dan penghindaran kemudharatan di dalam Islam.

\section{HASIL DAN PEMBAHASAN}

Hasil pengukuran disajikan secara berurutan pada 3 (tiga) tabel berikut. Tabel 1 merupakan tabulasi nilai rata-rata (\%) luas ruang termanfaatkan menurut hari dan waktu sholat. Tabel ini menunjukkan bahwa nilai ratarata kemanfaatan ruang utama MAIC paling tinggi adalah pada hari Jum'at pada waktu Sholat Fardhu Jum'at senilai 31,26\% dari total 
luas ruang utama. Ini setara dengan $1.112,33$ M2 ruang termanfaatkan dan 2.445,99 M2 tidak termanfaatkan. Sementara nilai rata rata kemanfaatan ruang utama terendah adalah pada hari Minggu pada waktu Sholat Isya' senilai $0,63 \%$ atau setara dengan 22,42 M2 ruang termanfaatkan dan 3.535,91 ruang tidak termanfaatkan.

Gambar 3 merupakan tabulasi nilai ratarata (\%) luas ruang termanfaatkan menurut waktu sholat. Pada tabel ini terlihat bahwa nilai rata-rata tertinggi luas ruang yang termanfaatkan adalah pada waktu Sholat Dzuhur $5,48 \%$ (termasuk Sholat Jum'at), setara dengan hanya $194,99 \mathrm{~m} 2$. Nilai rata-rata terendah adalah pada waktu Sholat Subuh $1,10 \%$ setara hanya $39,14 \mathrm{~m} 2$ ruang termanfaatkan. Total nilai rata-rata luas ruang termanfaatkan menurut waktu sholat selama 30 hari adalah 3,26\% atau setara dengan hanya $116,00 \mathrm{~m} 2$. Hal ini menunjukkan sangat besarnya rata-rata luas ruang yang tidak termanfaatkan mencapai $96,74 \%$.

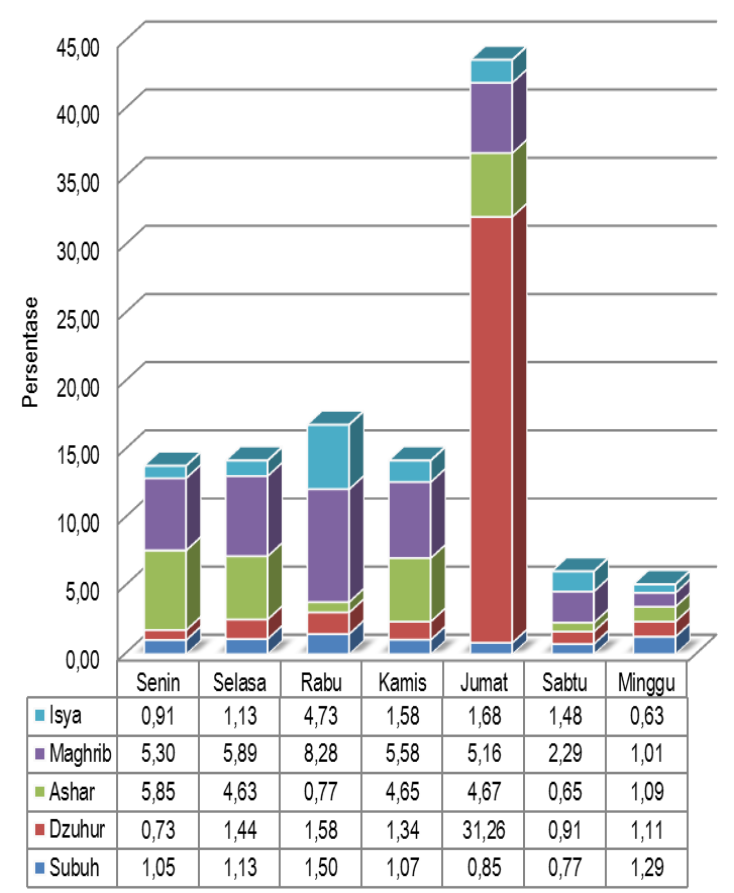

Gambar 3. Rata-rata (\%) Kemanfaatan Ruang Utama Menurut Hari dan Waktu Sholat, hasil pengamatan selama 30 hari

Gambar 4 memberikan gambaran hasil pengukuran nilai rata-rata (\%) luas ruang termanfaatkan menurut hari. Pada tabel ini terlihat bahwa nilai rata-rata tertinggi luas ruang yang termanfaatkan adalah pada hari Jum'at $8,72 \%$ (termasuk Sholat Jum'at), setara dengan hanya $310,28 \mathrm{~m} 2$. Nilai rata-rata terendah adalah pada hari Minggu 1,03\% setara hanya $36,65 \mathrm{~m} 2$ ruang termanfaatkan. Total nilai ratarata luas ruang termanfaatkan menurut waktu sholat selama 30 hari adalah 3,24\% atau setara dengan hanya $115,28 \mathrm{~m} 2$. Luas ruang yang tidak termanfaatkan mencapai $96,76 \%$.

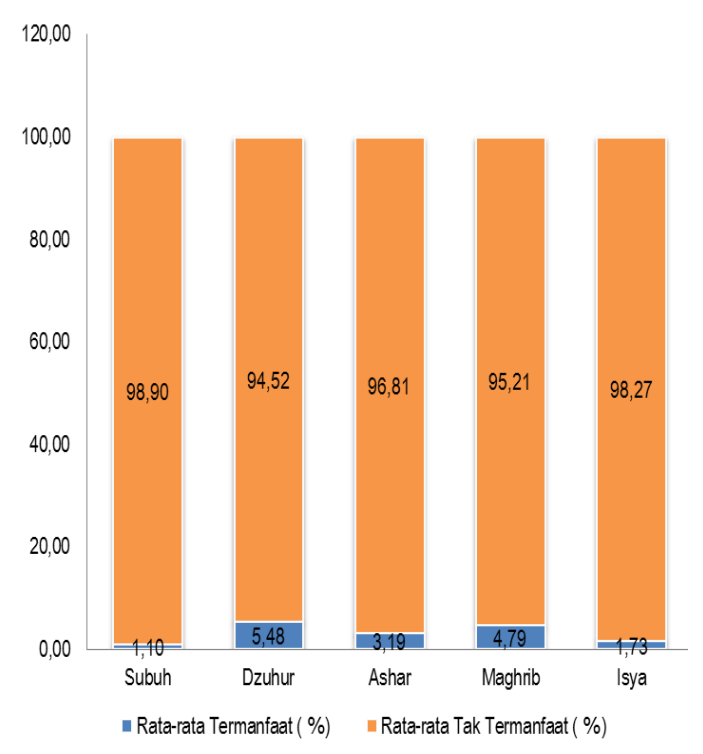

Gambar 4. Nilai Rata-rata (\%) Kemanfaatan Ruang Utama Menurut Waktu Sholat, dalam 30 hari

Hasil penelitian menunjukan sangat besarnya luas ruang utama MAIC yang tidak termanfaatkan dan mencapai nilai rata-rata lebih 95\%. Hal ini dikategorikan sebagai kemubaziran. Dalam pembangunan sebuah masjid, isu penting yang turut didiskusikan adalah biaya pembangunan yang tinggi, sehingga kadang kala mencapai angka yang dapat dikategorikan sebagai satu kemubaziran.

Biaya pembangunan yang tinggi namun ruang utama rata-rata hanya termanfaatkan kurang dari $4 \%$ merupakan ciri dari berlebihlebihan yang tidak didasari kelayakan dan analisis kebutuhan ruang utama masjid yang sesuai dengan jumlah dan keadaan masyarakat pada tempat tersebut.

Pada sisi lain ruang utama masjid, baik termanfaatkan atau tidak termanfaatkan tetap memerlukan perawatan dan penggunaan energi listrik secara rutin yang menyebabkan munculnya biaya operasional secara rutin pula. 
Semakin besar luas ruang akan paralel dengan meningkatnya biaya operasional tersebut. Biaya operasional ini menjadi mubazir ketika ruang utama masjid hanya kurang dari $4 \%$ yang termanfaatkan (Gambar 5).

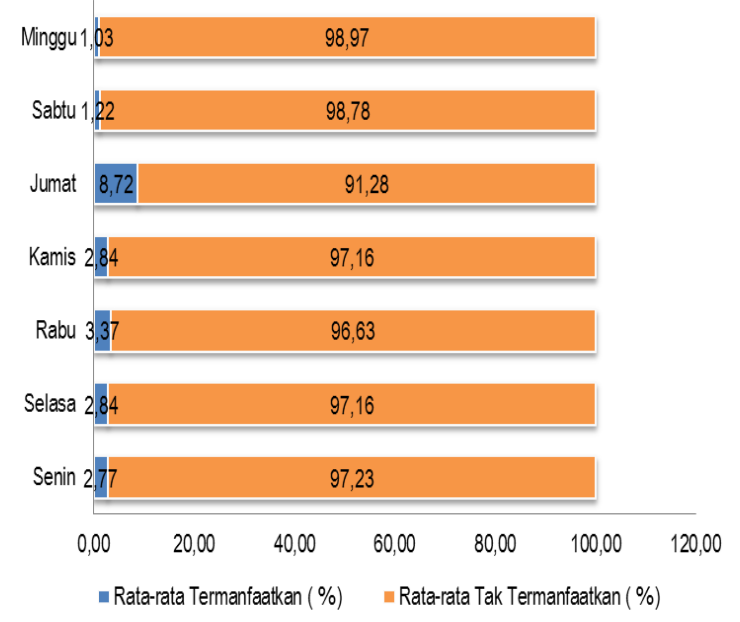

Gambar 5. Nilai Rata-rata (\%) Kemanfaatan Ruang Utama Menurut Hari, hasil pengamatan selama 30 hari

Keadaan ini tidak bersesuaian dengan gaya hidup Islami seperti yang diamalkan oleh Rasulullah saw seperti yang telah dinyatakan didalam hadits-hadits berikut:

Diriwayatkan dari Muhammad bin Ziyad: Aku pernah mendengar Abu Hurairah berkata,

"Ketika melihat seorang laki-laki, pembesar Bahrin, mengulurkan kainnya sampai menyapu tanah, aku berkata, 'pembesar datang, pembesar datang.",

Rasulullah saw bersabda, "Sesungguhnya, Allah tidak akan memandang (merahmati) orang yang mengulurkan kainnya (menyapu tanah) dengan sombong." (Shahih Muslim. Hadits ke-1359. h. 772.)

Diriwayatkan Anas (bin Malik) ra.:

Ketika kami sedang duduk-duduk bersama Nabi saw di dalam masjid, datang seseorang yang mengenderai seekor unta. Ia menyuruh unta itu berlutut di halaman masjid, mengikat kaki depannya lalu bertanya, "Siapa di antara kalian yang bernama Muhammad?" Pada waktu itu Nabi saw sedang duduk di antara kami (para sahabatnya) dengan bersandar pada kedua tangannya. Kami menjawab, "Lelaki berkulit putih yang duduk bersandar dengan tangan-nya." Orang itu melihat ke arah Nabi saw, "Hai, anak Abdul Muththalib." Nabi saw bersabda, "Aku ke sini untuk menjawab pertanyaanpertanyaanmu." Orang itu bertanya kepda Nabi saw, "Aku ingin menanyakan sesuatu dan tampaknya akan sulit engkau jawab. Jadi jangan marah." Nabi saw bersabda, "Tanyakan apa pun yang ingin kau tanyakan." Orang itu berkata, "Aku bertanya dengan nama Tuhanmu, Tuhan orang-orang sebelummu, Apakah Allah mengutusmu sebagai Rasul untuk seluruh manusia?" Nabi saw menjawab, "Demi Allah, benar." Lebih jauh orang itu bertanya, "Dengan nama Allah aku bertanya. Apakah Allah menyuruhmu mendirikan shalat lima waktu dalam sehari semalam?" Nabi saw menjawab, "Demi Allah, benar." Orang itu kemudian bertanya, "Demi Allah! Apakah Allah memerintahkan kepadamu untuk berpuasa pada bulan Ramadhan?" Nabi saw menjawab, "Benar, demi Allah." Orang itu bertanya lagi, "Demi Allah! Apakah Allah menyuruhmu mengambil zakat dari orang-orang kaya untuk diberikan kepada orang-orang miskin?" Nabi saw menjawab, "Demi Allah, benar." Lalu orang itu berkata, "Aku beriman atas semua yang diturunkan (Allah) kepadamu, aku dikirim sukuku sebagai seorang utusan, namaku fulan keluarga dari Bani Sa'd bin Bakar." (Shahih Muslim. Hadits ke-1387. h. 784.)

Berdasarkan hadits di atas, keadaan Rasulullah saw semasa berada di kalangan para sahabatnya di dalam masjid dilihat tiada perbedaan yang menunjukkan beliau sebagai seorang insan penting yang diutuskan oleh Allah, sebaliknya dilihat semuanya setara. Penampilan Baginda saw yang sederhana tanpa pakaian yang melambangkan keistimewaan serta Baginda saw yang duduk bersama dikelilingi oleh pengikut-pengikutnya tanpa berada di singgasana menunjukkan bahwa kesederhanaan adalah satu nilai penting dalam setiap aspek kehidupan, begitu juga dengan pembangunan sebuah masjid.

Dalam upaya menghindari kemubadziran dan mengamalkan kesederhanaan dalam pembangunan masjid, ruang utama namun tidak termanfaatkan sepatutnya dihindari. Dari segi fungsi, ruang utama MAIC dapat disiasati untuk 
menghindari kemubaziran dengan merubahnya menjadi ruang yang berfungsi tetap dan ruang yang berfungsi secara fleksibel. Ruang dengan fungsi tetap yaitu dengan menyediakan ruang untuk sholat secukupnya untuk menampung kegiatan sholat berjamaah 5 waktu (khusus pada MAIC: $\pm ; 3,26 \%$ x $3.558,33=116,00 \mathrm{~m} 2$ ). Sisanya menjadi ruang fleksibel yang dapat dimanfaatkan untuk kegiatan lain yang terkait dengan kegiatan di masjid sebagaimana contohcontoh yang telah di berikan oleh Rasullullah saw. Namun pada kegiatan temporer yang memerlukan luas yang besar (seperti Sholat Jum'at dan Sholat Ied), ruang fleksibel ini dapat difungsikan untuk ruang sholat berjamaah.

\section{KESIMPULAN}

Temuan penelitian mengindikasikan bahwa ruang utama MAIC dikategorikan sebagai kemubaziran, yang ditunjukkan dari hasil pengamatan selama 30 hari bahwa rata-rata luas ruang termanfaatkan kurang dari $4 \%$ (3,24\% berdasarkan hari dan 3,26 berdasarkan waktu sholat) dari total luas ruang utama secara keseluruhan.

Kemubaziran sedemikian rupa mampu dihindarkan jika perencanaan dan desain ruang utama diawali dengan analisis mengenai daya tampung berdasarkan besaran atau jumlah masyarakat yang diperkirakan akan menggunakannya. Sehingga ruang yang tidak termanfaatkan pada bangunan masjid dapat dihindari sebagai wujud pengamalan kesederhanaan.

\section{Daftar Pustaka}

Al Faruqi, I. \& Al Faruqi, L.L. (1986) The Cultural Atlas of Islam, New York: Macmillan Publishing Company.

Creswell, KAC. (1968) A Short Account of Early Muslim Architecture. Beirut: Librarie du Liban.

Frishman, M. \& Khan, H.U. (1994) The Mosque History, Architectural Development and Diversity, London: Thames \& Hudson Ltd.
Hamka (1958) Sejarah Perkembangan Pemurnian Ajaran Islam di Indonesia, Jakarta: Tintamas Djakarta.

Michell, G. Ed. (1978) Architecture of the Islamic World: Its History and Social Meaning, London: Thames \& Hudson Ltd.

Mohd. Tajuddin M Rasdi (2003) Crisis in Islamic Architecture. KALAM Papers: Crisis in Islamic Architecture, Johor Bahru: Pusat Kajian Alam Bina Dunia Melayu (KALAM).

Utaberta, Nangkula (2008) Arsitektur Islam: Pemikiran, Diskusi dan Pencarian Bentuk, Yogyakarta: Gadjah Mada University Press.

Utaberta, Nangkula (2003) KALAM Papers: Makna dan Arti Keindahan dalam Arsitektur Islam. Johor Bahru: Pusat Kajian Alam Bina Dunia Melayu (KALAM).

Utaberta, Nangkula (2003) Muslim Architecture in Peninsular Malaysia: Clasification of Styles and Probable Socio-Political Influence of Mosques. Johor Bahru: Pusat Kajian Alam Bina Dunia Melayu (KALAM).

Zein, A.B. (1999) Masjid-masjid Bersejarah di Indonesia, Jakarta: Gema Insani Press.

Ziesel, J. (1980) Inquiry by design: Tools for environment-behaviour research. California: Brooks/Cole Publishing Company. 